\title{
UPAYA MENINGKATKAN HASIL BELAJAR PASSING DAN DRIBBLING PERMAINAN BOLA BASKET MELALUI MODEL PEMBELAJARAN KOOPERATIF TIPE GROUP INVESTIGATION PADA PESERTA DIDIK KELAS XI-1 FARMASI SMK NEGERI 17 SAMARINDA \\ Baso Amiruddin S, Muh. Ramli Buhari, Naheria, Paryadi \\ Program Studi Pendidikan Jasmani Kesehatan Dan rekreasi basoamiruddin07@gmail.com
}

\begin{abstract}
Abstrak
Penelitian ini bertujuan untuk meningkatkan hasil belajar menggoper dan menggiring bola basket pada peserta didik kelas XI-1 farmasi SMK Negeri 17 Samarinda tahun ajaran 2019/2020 menggunakan model kooperatif tipe group investigation. Penelitian ini merupakan penelitian tindakan kelas (PTK). Penelitian ini dilaksanakan dalam dua siklus, yang terdiri dari perencanaan, pelaksanaan, observasi dan refleksi tindakan untuk tiap siklus. Subyek penelitian adalah murid kelas XI-1 farmasi SMK Negeri 17 Samarinda tahun ajaran 2019/2020 yang berjumlah 32 murid, 5 siswa dan 27 siswi. Sumber data untuk penelitian berasal dari murid dan guru. Teknik pengumpulan data yang digunakan dalam penelitian ini adalah dengan melakukan tes keterampilan, pengetahuan dan juga mengamati perilaku murid sebagai penilaian pada aspek sikap. Data analisis mengunakan teknik analisis deskriptif yang berdasarkan pada analisis kualitatif dan kuantitatif. Hasil dari penelitian menunjukan bahwa mengunakan model kooperatif tipe group investigation dapat meningkatkan hasil belajar passing dan dribbling bola basket pada murid dari prasiklus ke siklus satu dari siklus satu ke siklus dua. Dari analisis data yang diperoleh hasil siklus satu terjadi peningkatan hasil belajar menggoper dan menggiring bola basket yang tuntas yaitu $43,75 \%$ atau 14 murid yang tuntas. Sedangkan siklus dua peningkatan hasil belajar teknik dasar menggoper dan menggiring bola basket sebesar $100 \%$ atau 32 peserta didik yang tuntas. Bedasarkan hasil penelitian dapat disimpulkan bahwa mengunakan model pembelajaran kooperatif tipe group investigation tepat dalam pembelajaran bola basket khususnya teknik dasar passing dan dribbling.
\end{abstract}

Kata kunci: Peningkatan, Hasil Belajar, passing dan dribbling, Model Kooperatif Tipe Group Investigation.

\section{Pendahuluan}

Cabang olahraga bola basket dalam permainan ini sangat membutuhkan keterampilan dan bakat khusus, salah satunya untuk peserta didik SMK Negeri 17 Samarinda untuk meningkatkan hasil belajar pada materi bola basket. Pada proses pembelajaran olahraga pada materi bola basket guru mengajarkan materi bola basket kepada peserta didik kelas XI-1 farmasi dengan menggunakan model dan metode 
pembelajaran yang ada di Rancangan Pelaksanaan Pembelajaran (RPP) yaitu model pembelajaran dengan tipe komando dan ceramah. Pada saat proses pembelajaran berlangsung siswa lebih terlihat tidak aktif dan guru yang lebih aktif, hal ini yang menyebabkan siswa hanya mendengar dan tidak memperhatikan proses pembelajaran. Pada hasil evaluasi pembelajaran masih banyak terdapat peserta didik kelas XI-1 farmasi memiliki kemampuan kurang dalam melakukan teknik dasar menggoper ( passing ) dan menggiring (dribbling) bola basket, hal ini dapat diliat dari hasil nilai pada pembelajaran bola basket yang masih dibawah KKM.

Menguasai teknik passing dan dribbling bola basket ada beberapa tahapan yang perlu dipahami siswa dan siswi untuk meningkatkan hasil belajar menggoper (passing) dan menggiring (dribbling) yaitu posisi tubuh, langkah kaki, memegang bola, perkenaan telapak tangan pada bola dan pandangan. Pada saat peneliti melakukan observasi, siswa melakukan tehnik passing dan dribbling terdapat kesalahan yang dilakukan siswa yaitu posisi tubuh yang tegak ketika menggoper dan menggiring, memegang bola yang salah dengan cara memegang dua sisi bola, menggoper bola keteman terlalu keras serta tidak terarah, menggiring bola menggunakan telapak tangan, memukul bola, melihat bola, dan menggiring bola terlalu cepat sehingga bola menjadi tidak dapat di kontrol dengan baik.

Hasil belajar menggoper (passing) dan menggiring (dribbling) yang dicapai siswa dan siswi khususnya kelas XI-1 Farmasi SMK Negeri 17 Samarinda masih kurang memuaskan. Di dalam proses pelaksanaannya masih banyak siswa dan siswi dalam melakukan teknik passing dan dribbling bola basket kurang baik serta tidak maksimal dan dalam hal ini akan berdampak dalam permainan bola basket dan hasil evaluasi dalam belajar. Hal tersebut dapat dilihat berdasarkan hasil evaluasi belajar yang dicapai masih rendah. Masih ada beberapa siswa dan siswi yang nilai hasil belajarnya masih belum tuntas ketika pengambilan nilai. Untuk jumlah keseluruhan siswa dan siswi kelas XI-1 Farmasi yaitu 32 orang. Untuk yang tuntas dalam pengambilan nilai yaitu 11 orang, dan untuk yang belum tuntas yaitu 21 orang. Apabila di presentasekan maka jumlah siswasiswi yang tuntas adalah 34,37 \%, dan untuk siswa-siswi yang tidak tuntas adalah $65,62 \%$. Hal ini dikarenakan peserta didik kurang menguasai tehnik dasar menggoper (passing) dan menggiring (dribbling) bola basket dengan baik dan benar, sehingga tujuan belajar tidak terlaksana dengan baik.

Peneliti telah mengkaji dan meneliti tentang, upaya meningkatkan hasil belajar passing dan dribbling permainan bola basket menggunakan model pembelajaran 
kooperatif tipe group investigation pada siswa dan siswi XI-1 Farmasi SMK Negeri 17 Samarinda. Kemampuan menggoper (passing) dan menggiring (dribbling) bola basket pada siswa dan siswi akan mengalami kesulitan dalam memahami materi apabila guru tidak menggunakan model atau metode pembelajaran yang membuat siswa dan siswi lebih aktif dan mudah memahami materi pembelajaran. Untuk itu dalam penilitian ini peneliti ingin menggunakan model pembelajaran kooperatif Tipe group investigation (investigasi kelompok), dan untuk model pembelajaran kooperatif Tipe group investigation mempunyai konsep bentuk pembelajaran dengan cara siswa dan siswi belajar dan bekerjasama dalam kelompok secara kolaboratif dengan struktur kelompok yang bersifat heterogen (beragam) yang mempunyai tujuan yaitu siswa dan siswi dalam satu kelompok dapat bekerja sama dalam menyelesaikan permasalahan yang ada di setiap kelompok.

Berdasarkan uraian diatas peneliti tertarik untuk melakukan Penelitian Tindakan Kelas dengan judul " upaya meningkatkan hasil belajar passing dan dribbling permainan bola basket menggunakan model pembelajaran kooperatif tipe group investigation pada peserta didik XI-1 Farmasi SMK Negeri 17 Samarinda.

\section{Kajian Pustaka dan Pengembangan Hipotesis}

Asep Jihad (2013:1) berpendapat bahwa belajar merupakan kegiatan berproses dan merupakan unsur yang sangat fundamental dalam penyelenggaran jenis dan jenjang pendidikan, hal ini berarti keberhasilan pencapaian tujuan pendidikan tujuan pendidikan sangat tergantung pada keberhasilan proses belajar siswa disekolah dan lingkungan sekitarnya.

Azhar (2014 : 1) berpendapat bahwa belajar adalah suatu proses yang kompleks terjadi pada diri setiap orang sepanjang hidupnya. Proses belajar itu terjadi karena adanya interaksi antara seseorang dengan lingkungannya. Belajarpun terjadi kapan saja dan dimana saja. Salah satu tanda seseorang telah belajar adalah adanya perubahan tingkah laku pada yang ada pada diri setiap individu yang disebabkan terjadinya perubahan tingkat pengetahuan, keterampilan dan sikapnya.

Purwanto (2014:46) hasil belajar merupakan pencapaian tujuan pendidikan pada siswa yang mengikuti proses belajar mengajar. Tujuan pendidikan bersifat ideal, sedang hasil belajar bersifat aktual. Hasil belajar merupakan ralisasi tercapaianya 
tujuan pendidikan, sehingga hasil belajar yang diukur sangat tergantung pada pendidikannya.

Ahmad Susanto (2014: 5) berpendapat bahwa hasil belajar siswa adalah kemampuan yang dimiliki siswa setelah melakukan proses perolehan pengetahuan baru yang memungkinkan adanya perubahan perilaku. Siswa dikatakan berhasil dalam belajar apabila telah berhasil mencapai tujuan pembelajaran yang telah ditetapkan oleh guru sebelumnya. Hasil belajar menyangkut tiga aspek, yaitu aspek kognitif, aspek afektif, dan aspek psikomotor.

Mikanda Rahmani (2014:50) menjelaskan bahwa bola basket merupakan olahraga yang menggunakan bola dan dimainkan secara beregu. Tiap regunya dimainan oleh lima orang pemain. Olahraga ini pada umumnya dimainkan didalam ruangan tertutup (indoor). Berbeda dengan yang terjadi disekolah, dimana olahraga basket lebih banyak dimainkan di ruangan terbuka (outdoor). Cara memainkan olahraga ini adalah kedua tim saling berebut bola dengan mengutamakan kerja sama tim dan memasukkan bola ke dalam keranjang atau ring basket, sehingga mencetak angka.

Teknik dasar menggoper bola (Passing) menurut Sukma Aji (2016:57) yaitu Teknik passing adalah gerakan melempar bola ke teman satu timnya dengan menggunakan satu atau dua tangan. Teknik ini harus bisa dilakukan dalam permainan bola basket, karena untuk mencegah dari lawan yang ingin merebut bola.

Teguh Sutanto (2016:50) mengemukakan menggoper atau melempar bola terdiri atas tiga cara yaitu melempar bola dari atas kepala (overhead pass), melempar bola dari depan dada (chest pass) yang dilakukan dari dada ke dada dengan cepat dalam permainan, serta melempar bola memantul ke tanah atau lantai (bounce pass).

Teknik dasar menggiring bola (Dribbling) menurut Sukma Aji (2016:56) yaitu Teknik dribbling adalah teknik membawa bola untuk menghindari lawan agar bisa mencetak poin. Teguh Sutanto (2016:50) mengemukakan menggiring bola yaitu usaha membawa bola kedepan.

Muhajir (2014:39) mengemukakan bahwa menggiring bola adalah upaya membawa bola dengan cara memantulkan bola di tempat, memantulkan bola sambil berjalan dan memantulkan bola sambil berlari.

\section{Setting dan Objek Penelitian}


Berdasarkan judul yang penulis angkat dalam penelitian ini yaitu: Upaya Meningkatkan Hasil Belajar Passing dan Dribbling Permainan Bola Basket Melalui Model Pembelajaran Kooperatif Tipe Group Investigation Pada Peserta didik Kelas XI-1 Farmasi SMK Negeri 17 Samarinda, dapat di definisikan fokus penelitian ini adalah sebagai berikut :

a. Hasil belajar merupakan perubahan dari aspek sikap, pengetahuan maupun keterampilan yang didapat dari belajar. Hasil belajar adalah merupakan pengalaman yang diperoleh peserta didik yang mencakup bidang kognitif, afektif, dan psikomotorik.

b. Menggoper (passing) merupakan cara memberikan teman bola dengan cara melempar menggunakan tehnik chest pass, bounce pass, overhead dan menggiring (dribbling) bola basket merupakan suatu cara membawa bola kedepan dengan memantulmantulkan bola ke lantai dengan satu tangan atau secara bergantian baik dengan berjalan atau berlari. Hal yang perlu diperhatikan dalam menggiring bola basket adalah melindungi bola agar tidak mudah direbut oleh lawan.

c. Model pembelajaran kooperatif tipe group investigation merupakan salah satu tipe dari model pembelajaran kooperatif yang berupa kegiatan belajar yang memfasilitasi siswa untuk belajar dalam bentuk kelompok yang bersifat heterogen, dimana siswa dan siswi yang berkemampuan tinggi bergabung dengan siswa dan siswi yang berkemampuan rendah untuk belajar bersama, bekerjasama, memaksimalkan kondisi belajar, dan menyelesaikan suatu masalah dengan cara menginvestigasi masalah yang ada dengan arahan guru kepada siswa untuk mencapai tujuan belajar.

Tujuan peneliti melakukan penelitian tindakan kelas (PTK) ini yaitu untuk meningkatkan kemampuan hasil belajar pada aspek afektif, kognitif dan psikomotorik peserta didik kelas XI-1 Farmasi SMK Negeri 17 Samarinda. Diharapkan dengan adanya penelitian tindakan kelas ini dapat meningkatkan kemampuan peserta didik pada aspek afektif, kognitif dan psikomotorik.

Dalam Penelitian ini, penelitian tindakan kelas (PTK) dilaksanakan dalam 2 siklus, setiap siklus terdiri dari 2 kali pertemuan. Prosedur Penelitian Tindakan Kelas (PTK) 
dimulai dengan siklus pertama yang terdiri dari empat tahap kegiatan, yaitu perencanaan, pelaksanaan, pengamatan, dan refleksi yang saling berkaitan dalam satu siklus.

Instrumen penelitian yang digunakan dalam penelitian ini adalah instrument tes hasil belajar peserta didik. Instrumen ini berupa tes dalam bentuk soal essay dan praktik. Pada tes akhir yang diberikan yaitu bertujuan untuk mengukur peningkatan hasil belajar peserta didik setelah diterapkannya model pembelajaran kooperatif tipe group investigation. Bentuk instrument yang digunakan untuk mengukur hasil belajar peserta didik adalah tes tertulis dan praktik yang mencakup tiga aspek afektif, kognitif dan psikomotor.

Instrumen penelitian yang digunakan dalam penelitian ini adalah instrument tes hasil belajar peserta didik. Instrumen ini berupa tes dalam bentuk soal essay dan praktik. Pada tes akhir yang diberikan yaitu bertujuan untuk mengukur peningkatan hasil belajar peserta didik setelah diterapkannya model pembelajaran kooperatif tipe group investigation. Bentuk instrument yang digunakan untuk mengukur hasil belajar peserta didik adalah tes tertulis dan praktik yang mencakup tiga aspek penilaian yaitu sebagai berikut :

a. Instrumen tes dan penilaian dalam aspek afektif (sikap), dengan besaran penilaian skor yang diperoleh siswa di kali 100 dan dibagi pada skor maksimal.

b. Instrument tes dan penilaian dalam aspek kognitif (pengetahuan), dengan besaran penilaian skor yang diperoleh siswa di kali 100 dan dibagi skor maksimal.

c. Instrument tes dan penilaian dalam aspek psikomotor (keterampilan), dengan besaran penilaian skor yang diperoleh siswa di kali 100 dan dibagi skor maksimal. Tes ini diambil berdasarkan penilaian menggoper (passing) dan menggiring bola (dribbling) pada permainan bola basket.

Analisis data yang digunakan dalam penelitian ini adalah analisis data yang bersumber dari RPP, yaitu untuk mengetahui hasil belajar siswa dengan menggunakan rata-rata, presentase dan diagram yang diuraikan.

\section{Hasil dan Pembahasan}


Untuk melihat lebih jelas seluruh peningkatan yang terjadi, maka akan disajikan data prasiklus, siklus I, dan siklus II yang telah didapatkan dan terjadi peningkatan dari setiap siklusnya.

Tabel 4.6 Perbandingan nilai prasiklus, siklus I, dan siklus II dapat dilihat pada tabel berikut.

\begin{tabular}{|c|c|c|c|c|}
\hline No & Nama Peserta Didik & Prasiklus & Siklus I & Siklus II \\
\hline 1 & ANDYRA AGENG & 83 & 88 & 88 \\
\hline 2 & AYU NURAZIZAH & 72 & 84 & 92 \\
\hline 3 & CHERESIA VENERANDA V.T. & 72 & 91 & 92 \\
\hline 4 & DASTIK WIDYA NASTITI & 61 & 72 & 88 \\
\hline 5 & DEA SISKA & 61 & 78 & 85 \\
\hline 6 & FANNY LEVIANI & 61 & 75 & 92 \\
\hline 7 & FITRI WULANDHARI & 91 & 80 & 88 \\
\hline 8 & FRISKA FITRIANI & 80 & 81 & 85 \\
\hline 9 & HELMA PUTRI RINDIANI & 61 & 79 & 88 \\
\hline 10 & INUL OCTAVIA & 61 & 71 & 87 \\
\hline 11 & ISWANDA OLIVIA PUTRI & 83 & 91 & 91 \\
\hline 12 & KURNIA THALIA H. & 80 & 86 & 86 \\
\hline 13 & LIA HARDIANI & 83 & 84 & 90 \\
\hline 14 & MUHAMMAD AROFALDI N. & 72 & 70 & 88 \\
\hline 15 & MUHAMMAD BAYU A. & 83 & 79 & 90 \\
\hline 16 & MUHAMMAD NUR H.S. & 91 & 66 & 86 \\
\hline 17 & MUHAMMAD RASYID H.A & 61 & 63 & 90 \\
\hline 18 & MUSDAHLIA & 80 & 80 & 88 \\
\hline 19 & NABILA SATIA R. & 61 & 72 & 88 \\
\hline 20 & NANDA AYU NATASYA & 83 & 84 & 90 \\
\hline 21 & NINA & 61 & 78 & 92 \\
\hline 22 & NONI ANINDYA P. & 72 & 64 & 88 \\
\hline 23 & NOOR SARI AMELIA R. & 61 & 84 & 90 \\
\hline 24 & NUR ALVINA ZAHROH & 61 & 79 & 91 \\
\hline 25 & RAFIYANA FADILLAH & 72 & 81 & 93 \\
\hline 26 & RISMA ZAHRA SALSABILA & 72 & 83 & 90 \\
\hline 27 & ROHAYATUL JANNAH & 61 & 77 & 87 \\
\hline
\end{tabular}




\begin{tabular}{|c|l|c|c|c|}
\hline 28 & SARI NUR AISYAH & 91 & 87 & 93 \\
\hline 29 & SHEREN REGINAMONA & 61 & 77 & 92 \\
\hline 30 & SINDY DWI WIJAYANTI & 61 & 79 & 90 \\
\hline 31 & SITI MURIAH & 61 & 72 & 88 \\
\hline 32 & WAHYU JOKO PRASETYO & 61 & 74 & 90 \\
\hline \multirow{2}{*}{ Jumlah } & $\mathbf{7 1 , 0 9}$ & $\mathbf{7 8 , 4 1}$ & $\mathbf{8 9 , 2 5}$ \\
\hline \multirow{2}{*}{ Peningkatan } & $\mathbf{1 0 , 3 0 \%}$ & $\mathbf{1 3 , 8 2 \%}$ & $\mathbf{2 5 , 5 4 \%}$ \\
\hline
\end{tabular}

Prasiklus nilai rata-rata peserta didik sebesar 71,09 siklus I diperoleh nilai rata-rata sebesar 78,41 dan pada siklus II diperoleh nilai rata-rata peserta didik sebesar 89,25. Dapat dilihat bahwa terjadi peningkatan nilai rata-rata peserta didik dari prasiklus ke siklus I sebesar 7,32 atau 10,30\%, dan siklus I ke siklus II sebesar 10,84 atau 13,82\%. Jika dilihat dari data nilai awal yaitu prasiklus sebesar 71,09 dan nilai akhir yaitu siklus II sebesar 89,25 maka peningkatan hasil belajar peserta didik yang dilihat dari data awal hingga data akhir yaitu 18,16 jika di persentase peningkatan diperoleh adalah sebesar 25,54\%. Hal ini menunjukkan bahwa pada proses pembelajaran dengan menggunakan model Kooperatif tipe GI memberikan peningkatan terhadap hasil belajar dari prasiklus hingga siklus terakhir menunjukkan peningkatan yang signifikan.

Berdasarkan nilai rata-rata peserta didik yang telah di analisis diatas, peningkatan nilai rata-rata peserta didik pada seluruh siklus dapat disajikan dalam diagram di bawah ini seperti berikut.

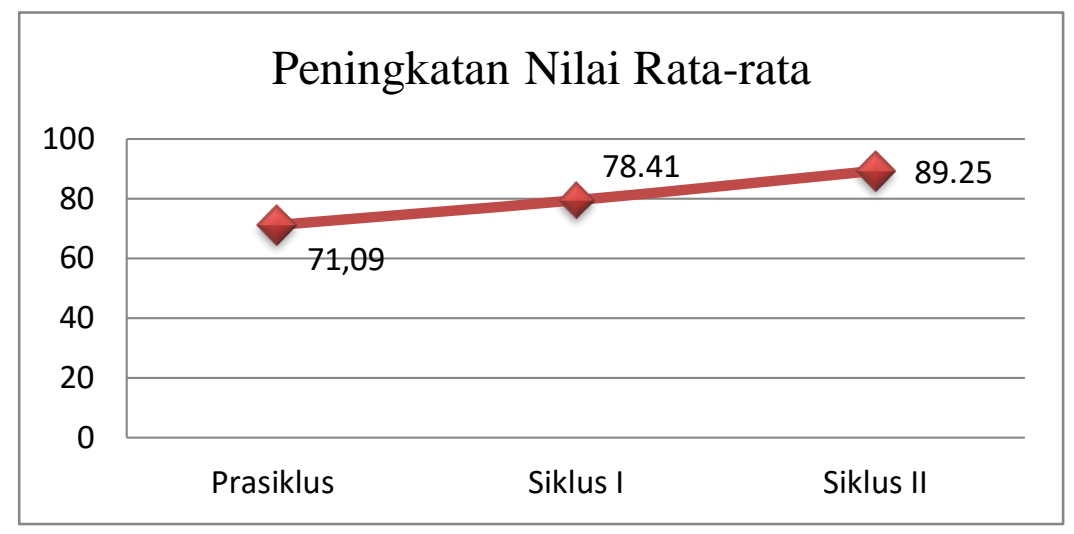

Gambar 4.1 Peningkatan Nilai Rata-rata Peserta Didik

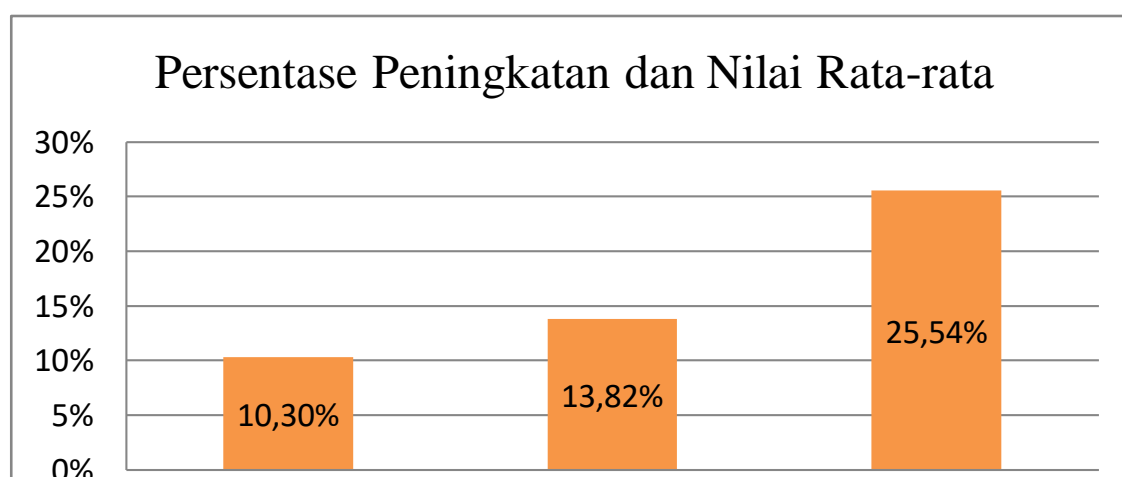




\section{Gambar 4.2 Persentase Peningkatan Nilai Rata-rata Peserta Didik}

Grafik 4.1 dan 4.2, terlihat bahwa nilai rata-rata dari prasiklus ke siklus I mengalami peningkatan dari 71,09 menjadi 78,41 atau meningkat sebesar 10,30\%, nilai rata-rata dari siklus I ke siklus II mengalami peningkatan dari 78,41 menjadi 89,25 atau meningkat sebesar $13,82 \%$, dan secara keseluruhan siklus yaitu prasiklus ke siklus II mengalami peningkatan dari 71,09 menjadi 89,25 atau meningkat sebesar 25,54\%.

Berdasarkan penjelasan tersebut, dapat dilihat dan disimpulkan bahwa peningkatan nilai rata-rata peserta didik untuk seluruh siklus mulai dari prasiklus sampai siklus II mengalami peningkatan yang signifikan.

\section{Kesimpulan dan Keterbatasan}

Berdasarkan dari hasil penelitian dan analisis data yang telah dilakukan, maka dapat disimpulkan bahwa dengan menerapkan model pembelajaran Kooperatif tipe Group investigation pada materi passing dan dribbling permainan bola basket terbukti dapat meningkatkan hasil belajar siswa kelas XI-1Farmasi SMK Negeri 17 Samarinda. Peningkatan tersebut terjadi sesudah diberikan perlakuan dimulai dari Prasiklus sebelum diberikan perlakuan nilai rata-rata siswa adalah 71,09 pada siklus I terjadi peningkatan yaitu rata-rata nilai siswa menjadi 78,41 dan siklus ke II 89,25. Jika peningkatan ini dipersentasekan, maka hasil dari peningkatan tersebut adalah $25,54 \%$ dan rata-rata nilai setiap siklusnya mengalami peningkatan.

Setelah siswa mengikuti proses pembelajaran materi passing dan dribbling permainan bola basket melalui model pembelajaran Kooperatif tipe group investigation terdapat peningkatan yang signifikan dalam proses hasil belajar siswa SMK Negeri 17 Samarinda. Dikarenakan pada model pembelajaran group investigation adanya proses menggamati dan mengganalisis gerakan siswa yang bertujuan mengaktifkan siswa dalam memahami materi dan berani menjadi contoh dari siswa lain. Model kooperatif tipe GI 
lebih membiasakan siswa untuk bekerjasama dalam team dan mengajari anggota kelempok yang belum bisa dalam melakukan passing dan dribbling permainan bola basket. Sehingga semua anggota kelompok terlibat aktif dalam pembelajaran.

\section{Referensi}

[1] Abdillah. 2015. Prinsip-prinsip belajar untuk pengajaran. Surabaya: usaha nasional

[2] Ahmad Susanto. 2014. Teori Belajar dan Pembelajaran di Sekolah Dasar. Jakarta: Kencana Prenada Media Group

[3] Asep Jihad, Abdul Haris. 2013 Evaluasi Pembelajaran. Yogyakarta. Multi Pressindo

[4] Azhar Arsyad. 2014. Media Pembelajaran. Jakarta: PT. Raja Grafindo Persada

[5] Dalyono. 2015. Psikologi Pendidikan. Jakarta: Rineka Cipta

[6] Hosnan. 2014. Pendekatan Saintifik dan Kontekstual dalam Pembelajaran Abad 21. Bogor: Ghalia Indonesia

[7] Mikanda Rahmani. 2014. Buku Super Lengap Olahraga. Jakarta : Dunia Cerdas

[8] Muhajir, Budi Sutrisno. 2014. Buku Guru Pendidikan Jasmani Olahraga dan Kesehatan. Jakarta. Pusat Kurikulum dan Perbukuan,Balitbang, Kemdikbud.

[9] Nana Sudjana. 2014. Penelitian Hasil Proses Belajar Mengajar. Bandung: Remaja Rosdakarya.

[10] Oemar Hamalik. 2015. Kurikulum dan Pembelajaran. Jakarta: Bumi Aksara.

[11] Purwanto. 2016. Evaluasi Hasil Belajar. Yogyakarta: Pustaka Pelajar.

[12] Rusman. 2015. Pembelajaran Tematik Terpadu. : Teori, Praktik dan Penilaian. Jakarta : Rajawali Pres.

[13] Rusman. 2016. Model-model Pembelajaran. Jakarta: Raja Grafindo Persada.

[14] Robert E.Slavin. 2011. Cooperative Learning. Bandung: Nusa Media.

[15] Sukma Aji. 2016. Buku Olahraga Paling Lengkap. Jakarta: PT Serambi Semesta Distribusi

[16] Suprijono, Agus. 2015. Cooperative Learning. Yogyakarta: Pustaka Pelajar.

[17] Teguh Sutanto. 2016 Buku Pintar Olahraga. Yogyakarta: Pustaka Baru Press.

[18] Winkel. 2016. Teori Belajar Dan Pembelajaran. Jakarta: Prenada Media Group 